\title{
Early Detection of the Orchid Flowering Gene PaFT1 in Tobacco Cells Using a GFP Reporter
}

\author{
Sri Wahyuningsih ${ }^{1,2 \S}$, Muhammad Dylan Lawrie ${ }^{1 \S}$, Budi Setiadi \\ Daryono $^{1,3}$, Sukarti Moeljopawiro ${ }^{1}$, Soenghoe Jang ${ }^{4}$, Endang Semiarti ${ }^{1,3, *}$ \\ ${ }^{1}$ Graduate Study Program of Biology, Faculty of Biology, Universitas Gadjah \\ Mada,Yogyakarta, Indonesia \\ ${ }^{2}$ Department of Biology, University of Lampung, Lampung, Sumatera, Indonesia \\ ${ }^{3}$ Department of Tropical Biology, Faculty of Biology, Universitas Gadjah Mada, \\ Yogyakarta, Indonesia \\ ${ }^{4}$ Biotechnology Center in Southern Taiwan (BCST) of Agricultural Biotechnology Research \\ Center (ABRC), Academia Sinica, Taiwan \\ $\S$ The two authors contributed equally in this paper
}

\begin{abstract}
Here we describe a novel method of using green fluorescence protein (GFP) as a reporter gene for early detection of an integrated T-DNA containing the orchid flowering gene, PaFT1 (Phalaenopsis aphrodite Flowering locus T1) in the tobacco genome. Functional assays that report the presence of exogenous DNA early in development are especially useful in plants where the desired phenotype is only apparent after long periods of vegetative growth. The objective of this study is to establish a method for detecting an inserted Phalaenopsis orchid flowering gene and examining its function in tobacco. The p35S::PaFT135S::GFP construct was introduced into Agrobacterium tumefaciens strain EHA101. Transformed tobacco leaves were cultured on MS medium with addition of $1 \mathrm{mgL}^{-1} \mathrm{NAA}+3 \mathrm{mgL}^{-1} \mathrm{BAP}+50 \mathrm{mgL}^{-1}$ Kanamycin +300 $\mathrm{mgL}^{-1}$ timentin for selection. Results showed bright green GFP fluorescent signals in 11 out of 15 (73\%) tobacco leaf cells at a 2-month time point after transformation. GFP and PaFT1 fragments were amplified in genomic PCR using GFP and PaFT1 specific primers. The accumulated PaFT1 transcripts were observed in 3 month-old transgenic tobacco plants containing p35S::PaFT1-35S::GFP. Green florescence was observed only in the transgenic plants at the 5 month-old stage but not in the wild type controls.
\end{abstract}

Keywords: Early flowering, GFP, PaFT1, reporter gene, tobacco

\section{Introduction}

Biotechnology is widely used in plant breeding to alter the genetic composition of plants to improve crop yields, alter cosmetic features, or facilitate transport. The alteration of genetic traits is performed by inserting genes from other plants, or even from other organisms, into the genome of the plant that is to be improved. In this way, new emerging genetic and physiological traits arise and these characters are passed to successive generations (Yuwono, 2006).

\footnotetext{
*Corresponding author:

Endang Semiarti

Department of Tropical Biology, Faculty of Biology, Universitas Gadjah Mada, Jl. Teknika Selatan, Sekip Utara,Yogyakarta 55281, Indonesia

E-mail: endsemi@ugm.ac.id
}

Changes in the properties of the transformant plant can be observed from its phenotype, but these may not be detectable for some time, or even until the plant reaches maturity. Selecting transformant plants could be made more efficient if the transformant plant could be detected earlier in its development. Thus, we have designed a system that relies on the plasmid-based genomic insertion of a fluorescent reporter gene to indicate that transformation has taken place. Our system spesifically reports the expression of flowering genes before the flowering phenotype can be observed. A number of systems were considered, including screenable markers such as $\beta$ glucuronidase (GUS) assay, and luciferase. However, as enzymatic assays both luciferase and GUS assays require the 
addition of an enzyme substrate to visually detect the result. Therefore we chose an approach based on Green Fluorescent Protein (GFP). GFP is a $27-\mathrm{kDa}$ protein (Xia et al., 2002), which emits bright light when exposed to blue light or ultraviolet radiation (UV) (Brito et al., 2013). GFP is widely used because it does not require substrates or exogenous cofactors for fluorescence (Stewart, 2005; Puchta, 2003) and does not destroy the tissues of transformants (Hraska et al. 2006). For these reasons, GFP was selected as the reporter gene to improve early detection of flowering genes.

In this research, the construction of a plasmid based on pGAS101 was carried out by inserting GFP as a reporter gene. The main gene on pGAS101 plasmid is PaFT1. PaFT1 gene is one of FT homologous genes isolated from P. aphrodite (Jang et al. 2015). Analogous to Arabidopsis as the model plant, overexpression of the PaFT1 gene is expected to accelerate flowering in plants. GFP was used as an evaluation tool of transformation parameters. Cells and tissues expressing GFP could be distinguished easily from those that do not express GFP without destroying the tissue sample, and can facilitate separating transformants and non-transformants (Hraska et al., 2006). GFP expression is indicated by green fluorescence, while the nontransformant retains its natural red autofluorescence after being exposed under light with a wavelength of $480 \mathrm{~nm}$ (Ghorbel et al., 1999).

Plasmid pGAS101 also includes the selection marker genes Neomycin Phosphotransferase (NPT) and tetracycline resistance $\left(\right.$ tet $\left.^{R}\right)$ genes. The selection marker genes are important for the development of plant transformation technology, because it allows the identification and isolation of cells expressing the cloned DNA and for monitoring and selecting offspring of the transformants (Miki and McHugh, 2004).

A number of transformation methods, which could be used to transfer foreign genes include particle bombardment, Agrobacterium tumefaciens-mediated, electroporation with protoplasts/protocorm, seed imbibition and transformation through pollen tube (Chai and $\mathrm{Yu}, 2007$ ). Transformation using Agrobacterium is an indirect transformation technique, which is the most frequently used. This technique has several advantages including transformation efficiency with higher copy numbers of single genes and ease of use with simple laboratory equipment. The Agrobacterium-mediated transformation method is commonly used to create transgenic plants, because it has more advantages compared to direct gene transfer methods such as particle bombardment, electroporation and silicon carbide fibers. The advantages include (1) stable gene expression; (2) a low number of transgene copies, (3) large DNA segments are able to be transferred (Ko and Korban, 2004).

Ti plasmid in a cell of $A$. tumefaciens contains a DNA fragment called T-DNA (sized 10-30 kb), which can integrate into the DNA of the plant cell nucleus. The Ti plasmid in A. tumefaciens cell is currently developed as a vector to insert foreign DNA into plant cells (Yuwono, 2006). This process requires functional transgenic constructs, including the desired main gene, promoter guiding the expression, marker genes, the transgene insertion into the Ti plasmid and the transformation of T-DNA contained in the plasmid into Agrobacterium cells (Mohammed and Abalaka, 2011).

In this study, a binary vector containing p35S::PaFT1-35S::GFP construct was then transferred into $A$. tumefaciens strain EHA101 and tobacco leaves. The detection of GFP at the beginning of plant growth indicates that $P a F T 1$ has integrated into plant genome. The p35S::PaFT135S::GFP/A. tumefaciens strain EHA101 is an efficient system for early detection and functional analysis of Flowering Gene PaFT1 in tobacco, and it assumed will also work in orchid and other plant species. In the future, the success of PaFT1 and GFP gene insertion will provide a means to more efficiently select for transformant plants that use exogenous PaFT1 flowering genes to accelerate flowering in plants. 


\section{Materials and Methods}

\section{Plant materials and bacterial strains}

Plant materials used as explants in this study were leaf dishes from two months old tobacco (Nicotiana tabacum L. var. Kemloko 1). The in vitro seedlings were cultivated on Murashige and Skoog (MS) medium, under white continuous light, at $(25 \pm 2)^{\circ} \mathrm{C}$ room temperature. The leaf dishes were used as explants for Agrobacterium-mediated genetic transformation of p35S::PaFT1-35S::GFP /EHA101 construct. For bacterial strains, Eschericia coli strain DH5a, A. tumefaciens strain EHA101, and E.coli containing pSK35S::GFP, pGAS101 plasmid were used to construct 35S::PaFT1::GFP. The pGAS101 plasmid (12.2 kb in length) was constructed previously to express PaFT1 gene using Cauliflower Mosaic Virus (CaMV) promoter 35S, it contained Neomycin Phosphotransferase II (NPT II) gene, which encodes a resistance character against the antibiotic kanamycin as a selection marker. The pSK35S::GFP (15.8 kb in lengths) plasmid was obtained from Prof. Chiyoko Machida (Chubu University, College of Bioscience and Biotechnology, Japan) that was constructed based on the pSK1 plasmid (Kojima et al., 1999). The plasmid carries GFP gene between $\mathrm{XbaI}$ and NotI restriction sites, which ws used as reporter in this research.

\section{Insertion of 35S::GFP fragment into pGAS101 plasmid}

The plasmid pGAS101 and pSK35S::GFP were isolated from $E$. coli using alkaline lysis method following the instruction manual of plasmid isolation kits (Qiagen, UK). The isolated pSK35S::GFP plasmids were cut using EcoRI restriction enzymes, and then separated using electrophoreses and visualized with a UV Transilluminator. The obtained p35S::GFP fragment bands were cut from the gel and extracted using JETQUICK Gel Extraction Spin Kit following the manual instruction (Genomed, The Netherlands). The gel extraction product was checked by PCR using 2 pairs of specific primers: the sGFP Fw (5'ACGAGAAGCGCGATCACAT-3') - Nos Rev (5'-GTATAATTGCGGGACTCTAATCA-3') primer pair. The pGAS101 plasmid containing PaFT1 gene, which was previously cut using EcoRI restriction enzyme, and the p35S::GFP fragment was ligated to pGAS101 using Ligation High-DNA ligase at $16^{\circ} \mathrm{C}$ for 30 minutes. The presence of ligation products was checked using PCR with sGFP Fw and Nos Rev primers as before. The p35S::PaFT135S::GFP plasmid (16.2 kb in length)was constructed as shown in Figure 1.

\section{Transformation of p35S::PaFT1-35S::GFP plasmid into E. coli strain DH5a}

Before the transformation, competent cells of E. coli strain DH5a were prepared according to the methods described in Sambrook and Russell (2001). Competent cells were subjected to transformation through the heat shock method. A volume of $800 \mu \mathrm{L}$ of competent cells was divided into 8 microtubes with $100 \mu \mathrm{L}$ competent cells each. A mixture of competent cells and p35S::PaFT1-35S::GFP plasmid were soaked in liquid SOC medium in a microtube and the obtained mixture was incubated for 45 minutes in water bath at $37^{\circ} \mathrm{C}$. A $100 \mu \mathrm{L}$ culture was taken from SOC medium, then inoculated it onto SOB solid medium plate containing $20 \mathrm{mM} \mathrm{MgSO}_{4}$ and $50 \mathrm{mgL}^{-1}$ of kanamycin antibiotic using the spread method, and then it was incubated at $37^{\circ} \mathrm{C}$. Colony PCR was performed to ensure that bacterial plasmids contained pGAS101 using a pair of degenerate primers DegPaFT1 (F1: 5'-GAKATGAATAGAGAGASRGAC-3') and DegPaFT1R1 (5'-TCAATCYTGCATYCTTCTTCC-3'), and pSK35S::GFP was checked using the primers of sGFP Fw (5'ACGAGAAGCGCGATCACAT-3') and Nos Rev primer (5'-GTATAATTGCGGGACTCTAATCA-3'), using PCR reactions with the following parameters: $94^{\circ} \mathrm{C}$ for $40 \mathrm{sec}$ (initial denaturation); $94^{\circ} \mathrm{C}$ for $30 \mathrm{sec}$ (denaturation); $60^{\circ} \mathrm{C}$ for $40 \mathrm{sec}$ (annealing) for sGFP Fw and Nos Rev primer pair, $54^{\circ} \mathrm{C}$ for $40 \mathrm{sec}$ for DegPaFT1 F1 and R1 primer pair; $72^{\circ} \mathrm{C}$ for 50 seconds (extension) and $72^{\circ} \mathrm{C}$ for $8 \mathrm{~min}$ (final extension), repeated for 40 cycles. The amplification products were checked using electrophoresis and visualized by a UV Transilluminator. 
Bacterial transformation by insertion of p35S::PaFT1::GFP plasmid into A. tumefaciens strain EHA101

The p35S::PaFT1-35S::GFP plasmids were transferred into A. tumefaciens competent cells, following procedures described by Widyasari and Suhandono (2007) with modification. A. tumefaciens competent cells in a volume of $100 \mu \mathrm{L}$ in a $1.5 \mathrm{ml}$ Eppendorf tube were mixed with $1 \mu \mathrm{L}$ plasmid in cold condition with liquid nitrogen for 5 minutes. The mixture was then incubated at $37^{\circ} \mathrm{C}$ for $25 \mathrm{~min}$. A volume of $1 \mathrm{~mL}$ liquid LB medium was added into the tube, and then the bacteria were grown at room temperature $\left(28^{\circ} \mathrm{C}\right)$ for 3 hours with shaking at $50 \mathrm{rpm}$. Bacterial cells were later harvested by centrifugation at 12,000 rpm for $30 \mathrm{sec}$. Pellets were suspended with $1 \mathrm{~mL}$ LB. After that, $200 \mu \mathrm{L}$ cell suspension was spread into the selection media (LB +5 $\mathrm{mgL}^{-1}$ tetracycline antibiotics $+50 \mathrm{mgL}^{-1}$ kanamycin), and then incubated at $28^{\circ} \mathrm{C}$ for two days to obtain transformed colonies. The transformation results were checked by PCR with primer pair of Deg PaFT F2 and R1 to detect the presence of PaFT1, and sGFP Fw and Nos Rev to detect GFP, in the same way of that used in E.coli. The recombinant p35S::PaFT1-35S::GFP / A tumefaciens strain EHA101 was then ready to be used for genetic transformation in tobacco leaf explants.

\section{Transfer of T-DNA containing p35S::PaFT1- 35S::GFP fragment into tobacco leaves}

A single colony of $A$. tumefaciens strain EHA101 containing p35S::PaFT1-35S::GFP was cultured in a $15 \mathrm{~mL}$ corning tube containing $2 \mathrm{~mL}$ LB liquid medium with 50 $\mathrm{mgL}^{-1}$ kanamycin and $5 \mathrm{mgL}^{-1}$ tetracycline antibiotics, incubated at $28^{\circ} \mathrm{C}$ for $48 \mathrm{~h}$ on a rotary shaker. A volume of $100 \mu \mathrm{l}$ Agrobacterium culture was added to $10 \mathrm{~mL}$ LB medium with $50 \mathrm{mgL}^{-1}$ kanamycin and 5 $\mathrm{mgL}^{-1}$ tetracycline antibiotics, and incubated at $28^{\circ} \mathrm{C}$ for $48 \mathrm{~h}$ on a rotary shaker. Bacteria were then harvested by centrifugation at 6,000 rpm for $3 \mathrm{~min}$. Bacterial cells pellet obtained was suspended in $10 \mathrm{~mL}$ liquid MS medium without sugar. After that, $2 \mathrm{~mL}$ bacterial culture was poured into $8 \mathrm{~mL}$ liquid MS

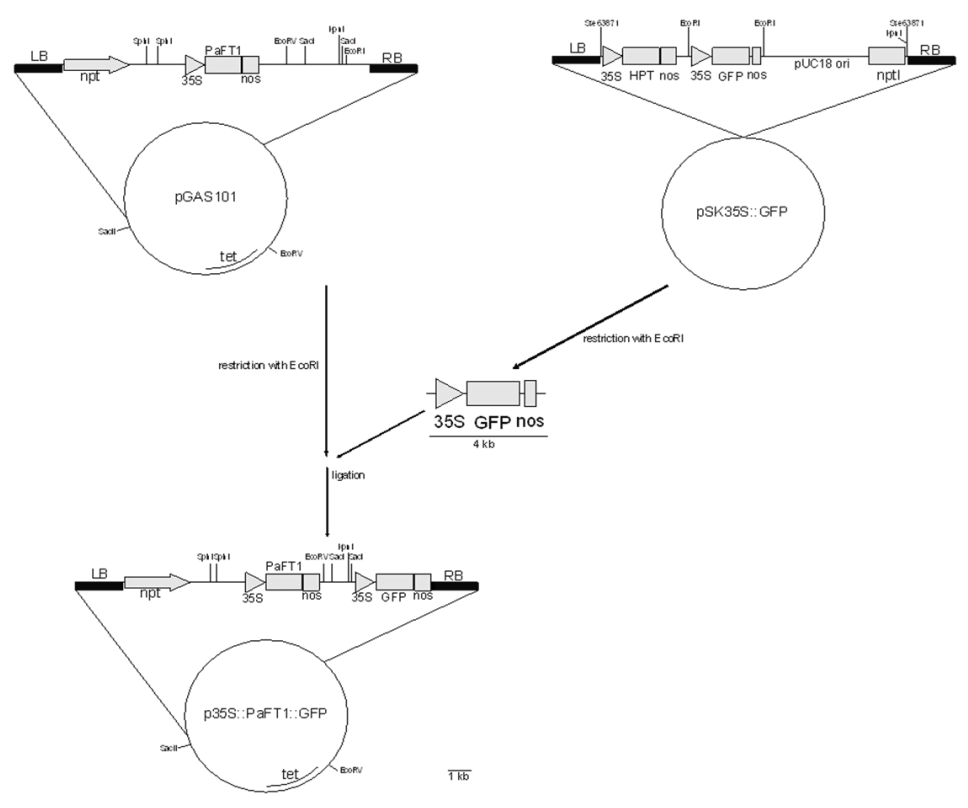

Figure 1. Construction of p35S::PaFT1-35S::GFP. The fragment of 35S::GFP (4,000 bp in size) in pSK35S::GFP plasmid was located between 2 EcoRI restriction sites, from which we cut the 35S::GFP fragment from the plasmid with EcoRI restriction enzyme. The pGAS101 plasmid has a single EcoRI restriction site, which facilitated linearization with EcoRI and subsequent insertion into 35S::GFP. The 35S::GFP DNA band with a size of 4,000 bp containing fragment were cut by EcoRI, and then gel extracted using Jet quick gel extraction kit (Genomed, Netherlands). The fragment of 35S::GFP and opened pGAS101 were mixed in a ratio 3:1, than ligated with T4 DNA ligase. The results of DNA ligation were checked using PCR with a pair of primers, the sGFP Fw and the Nos Rev. PCR products were visualized using UV Transilluminator. The final recombinant plasmid contains p35S::PaFT135S::GFP cassette. 
medium without sugar, and then homogenized. Next, the in vitro leaf explants $\left(1 \mathrm{~cm}^{2}\right.$ in size) were soaked into bacterial suspension for $30 \mathrm{~min}$. Leaf explants were later drained on sterile filter papers, then planted on MS medium with addition of 1 $\mathrm{mgL}^{-1} \mathrm{NAA}, 3 \mathrm{mgL}^{-1} \mathrm{BAP}$, and $100 \mathrm{mgL}^{-1}$ acetosyringone, then it were incubated in the dark room for 3 days. The transformed explants were then washed using $1,000 \mathrm{mgL}^{-1}$ timentin for 5 minutes, then rinsed its with liquid MS medium without sugar twice for 3 min each. Finally, the explants were dried up with sterile filter papers and transferred onto MS solid medium with addition of $1 \mathrm{mgL}^{-1} \mathrm{NAA}, 3$ $\mathrm{mgL}^{-1} \mathrm{BAP}, 50 \mathrm{mgL}^{-1}$ kanamycin, and 300 $\mathrm{mgL}^{-1}$ timentin for maintenance to form buds. About 2 months after Agrobacterium infection, some leaf pieces were analyzed for GFP expression, leaf pieces were placed on object glass, dropped with glycerin, covered with a cover glass, and then was observed with a fluorescent microscope under UV light, and photographed using Canon IXUS digital camera (Japan).

\section{Analysis of PaFT1 expression in transgenic tobacco plants}

Detection of gene expression was performed by isolating mRNA from young leaves of 3 months old of p35S::PaFT135S::GFP containing tobacco transformant plants, followed with cDNA synthesis from the mRNA. Total RNA was isolated using Total RNA Mini Kit Plant (Geneaid) and cDNA was synthesized from mRNA using Thermo ScientificTM RevertAidTM First Strand cDNA Synthesis Kit (Thermo Fisher Scientific Inc.). To detect the expression of PaFT1 gene in putative transgenic, RT-PCR was performed. The cDNA was used as template for RT-PCR analysis using the primers specific for the PaFT1 gene (deg PaFT F2 and R1) in putative $P a F T 1$ transgenic plants. RTPCR was also conducted for GFP gene using a pair of sGFP Fw and Nos Rev primers.

Phenotypic analysis of transgenic tobacco plants containing p35S::PaFT1-35S::GFP

Two month-old regenerated plants from leaf explants cultivated on MS medium with addition of $3 \mathrm{mg} \cdot \mathrm{L}^{-1} \mathrm{BAP}+1 \mathrm{mg} \cdot \mathrm{L}^{-1} \mathrm{NAA}$ and $50 \mathrm{mg} . \mathrm{L}^{-1}$ Kanamycin $+300 \mathrm{mg} . \mathrm{L}^{-1}$ timentin were transferred into MS medium for rooting. The plants were transferred into soil in pots and maintained in a greenhouse with natural environmental conditions and light photoperiods. The number of leaves, length of stem and time until detection of fluorescence were measured.

\section{Results and Discussion}

\section{Construction of p35S::PaFT1-35S::GFP}

The 35S::GFP that originally came from pSK35S::GFP plasmid was successfully inserted into pGAS101 (Figure 2). Figure 2A shows isolated $12.2 \mathrm{~kb}$ circular plasmid DNA of pGAS101 DNA and pSK35S::GFP $(12 \mathrm{~kb})$. EcoRI-digested plasmid showed a single linear plasmid of pGAS101. On the other hand, pSK35S::GFP was split into two bands: $8 \mathrm{~kb}$ and $4 \mathrm{~kb}$, indicating that pGAS101 has only one EcoR1 restriction site, and pSK35S::GFP has 2 EcoR1 restriction sites (Figure $2 \mathrm{~B}$ ). The presence of GFP in these two plasmids was confirmed by PCR analysis using sGFP Forward primers and Nos-ter primers, that resulted in $350 \mathrm{bp}$ amplified DNA fragments.

The linear plasmid DNA pGAS101 was ready to be inserted with GFP gene. A 35S::GFP DNA fragment of about $4 \mathrm{~kb}$ in length was gel extracted with the Jet quick gel extraction kit (Genomed).

DNA bands resulting from amplified DNA pSK 35S::GFP using PCR with primers of sGFP Fw and Nos Rev were evaluated by gel extraction for the presence GFP gene. As a negative control experiment, the detection of HPT gene was checked using a pair of HPT primers (HPT Fw and HPT Rev). PCR products were then checked using electrophoresis and visualized using a UV Transilluminator (Figure 3). The presence of GFP was detected. This data confirmed that the GFP had been amplified.

Products of gel extraction process targeting 35S::GFP fragment were mixed with pGAS101 plasmids, which were already digested with EcoRI and ligated with T4 DNA ligase. The ligation mixture was then incubated 

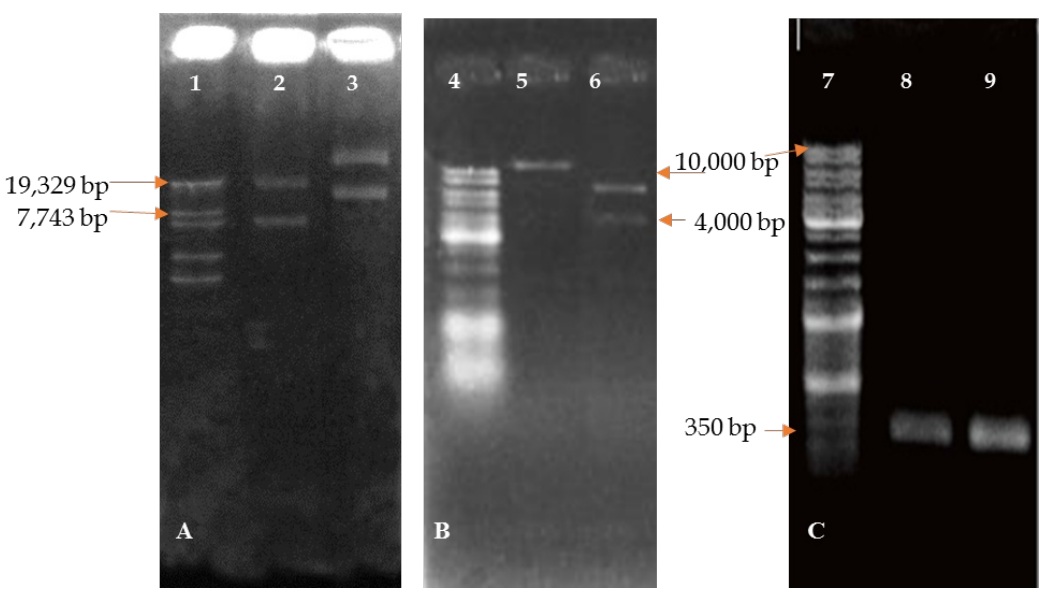

Figure 2. Confirmation of pGAS101 and pSK35S::GFP plasmids. (A) Isolated plasmid DNA of pGAS101 and pSK35S::GFP plasmids; (B) EcoRI restriction enzyme-digested pGAS101 and pSK35S::GFP plasmids; (C) Amplified DNA from pSK35S::GFP [Lane 1. Marker $\lambda$ /styI DNA, lane 2. pGAS101 plasmid DNA, lane 3. pSK35S::GFP plasmid DNA, lane 4. Marker of $1 \mathrm{~kb}$ DNA ladder, lanes (1, 4 and 7). EcoRI restriction enzyme digested pGAS101 (5) and pSK35S::GFP plasmid (6); GFP amplified DNA from pSK35S::GFP (8 and 9)].

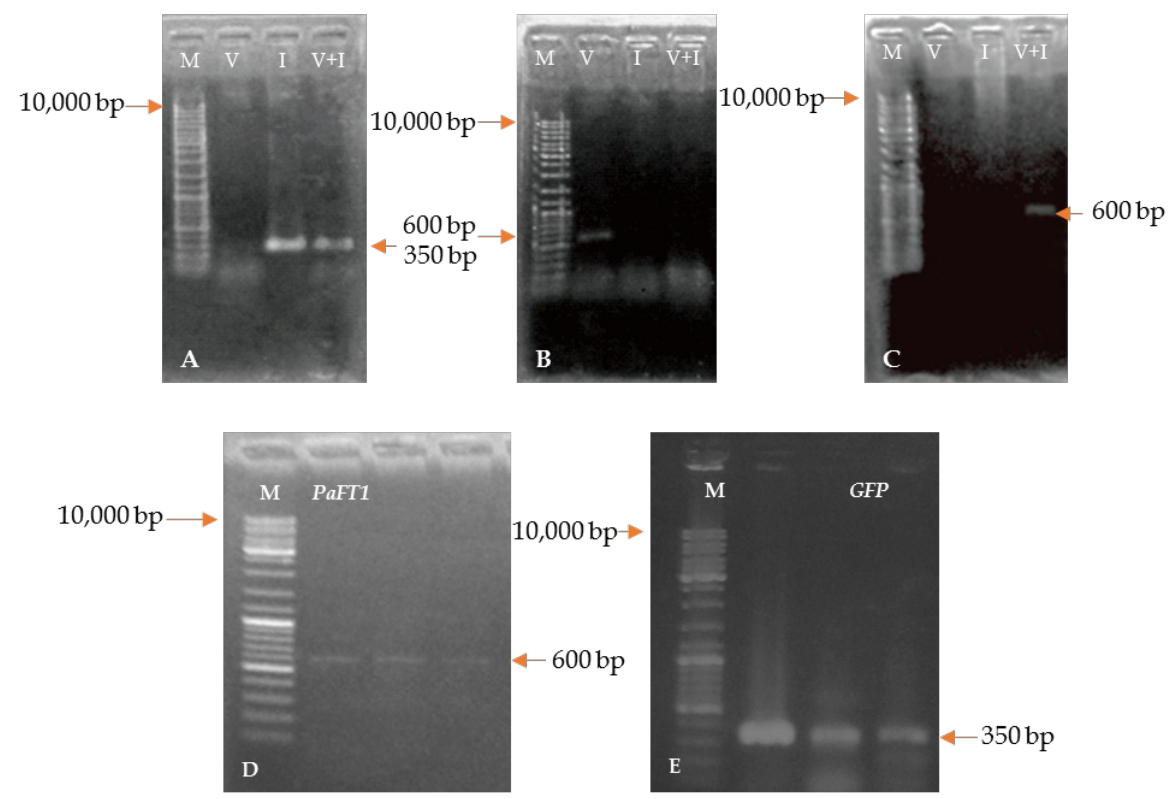

Figure 3. Detection of PaFT1 and GFP in bacterial plasmid. (A, B, C) Amplified of PaFT1 and GFP from E. coli DH5a and (D, E) A. tumefaciens EHA101 using GFP and PaFT primers. (A) sGFP, (B) DegPaFT $\left(54^{\circ} \mathrm{C}\right)$, and $(\mathrm{C})$ DegPaFT $\left(57^{\circ} \mathrm{C}\right)$. PCR products matched the size of GFP (350 bp) from a colony containing pSK35S::GFP (I) and a colony of p35S::PaFT1::GFP (V+I), while products matching with size of PaFT 1 (600bp) were obtained from a colony of pGAS101 (V) and a colony of p35S::PaFT1::GFP (V+I). (D) PaFT1 and (E) GFP from $p 35 S:: P a F T 1:: G F P / A$. tumefaciens EHA 101, (M) 1kb DNA ladder.

at temperature of $37^{\circ} \mathrm{C}$ for 30 mins. Products of the ligation process were used to transform the E.coli strain DH5a competent cells using the heat shock method. The heat shock method takes advantage of the membrane permeability created when cells undergo sudden temperature changes in a short period. Competent cells were diluted in $\mathrm{CaCl}_{2}(0.1 \mathrm{M})$ cold solution (Sambrook and Russell, 2001) to induce competence so the cells could accept foreign DNA molecules and to undergo transformation (Madigan et al., 2012). The E.coli competent cells were obtained by inducing the bacterial cells with $\mathrm{CaCl}_{2}$ treatment. The treatment resulted in cells that could be transformed by allowing DNA to 
M p 2 p35::PaFT1::GFP
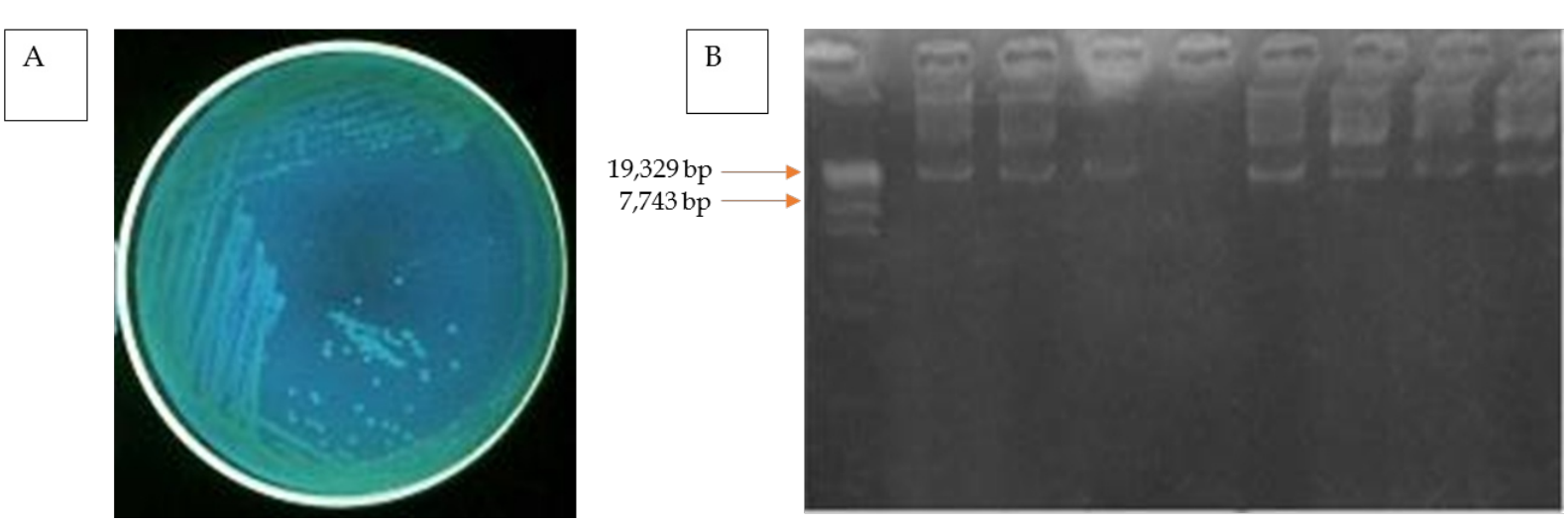

Figure 4. p35S::PaFT1-35S::GFP plasmid/A. tumefaciens EHA101. (A) Colonies of A. tumefaciens bacterial culture; (B) Isolated plasmid DNA of p35S::PaFT1-35S::GFP / A. tumefaciens EHA101, M=Marker ( $\lambda /$ styI).
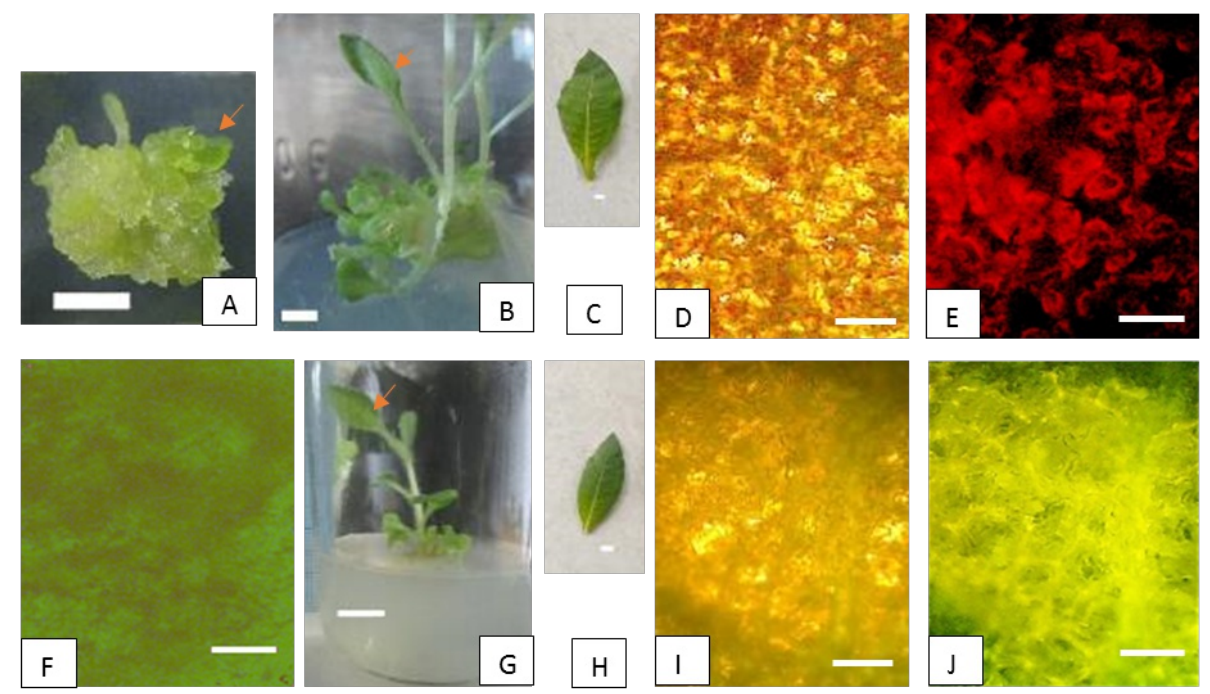

Figure 5. Expression of GFP in leaves of transgenic tobacco containing p35S::PaFT1-35S::GFP. (A) The 1.5 months old leaf culture of transgenic tobacco containing p35S::PaFT1-35S::GFP on MS medium $+1 \mathrm{mgL}^{-1} \mathrm{NAA}, 3 \mathrm{mgL}-1$ BAP, $50 \mathrm{mgL}^{-1}$ kanamycin, and $300 \mathrm{mgL}^{-1}$ timentin; (F) The callus explants exposed under UV light illumination showed green fluorescence; (B) A 2 months old plantlet of Wild type/non transformed on MS medium $+1 \mathrm{mgL}^{-1}$ NAA, $3 \mathrm{mgL}^{-1} \mathrm{BAP}$; (C) Leaf of (B); (D) 2 months old Wild type/non transformed leaves examined under bright light, and under UV light (E); (G) A 2 month-old plantlet of transgenic tobacco containing p35S::PaFT1-35S::GFP on MS medium + $1 \mathrm{mgL}^{-1} \mathrm{NAA}, 3 \mathrm{mgL}^{-1} \mathrm{BAP}, 50 \mathrm{mgL}^{-1}$ kanamycin, and $300 \mathrm{mgL}^{-1}$ timentin; (H) Leaf of (G); (I) the leaf of 2 month-old plantlet of transgenic tobacco containing p35S::PaFT1-35S::GFP under white light and under UV light $(J)$. The bright green fluorescence was detected in the leaf of transformant $(J)$, but not in wild type (E) that showed red autofluorescence. Bars (A, B, C, G, H) 1 cm; Bars (D, E, F, I, J) $100 \mu \mathrm{m}$.

Table 1. The initiation of flowering in transgenic tobacco containing p35S::PaFT1-35S::GFP.

\begin{tabular}{|c|c|c|c|c|c|c|c|c|c|c|}
\hline \multirow[t]{2}{*}{ Treatment } & \multirow[t]{2}{*}{$\begin{array}{l}\text { Number } \\
\text { of dish }\end{array}$} & \multirow[t]{2}{*}{$\begin{array}{l}\text { Kanamycin } \\
\text { positive }\end{array}$} & \multirow[t]{2}{*}{$\begin{array}{c}\text { PCR } \\
\text { positive }\end{array}$} & \multirow[t]{2}{*}{$\begin{array}{c}\text { GFP } \\
\text { positive }\end{array}$} & \multicolumn{2}{|c|}{$\begin{array}{l}\text { Number } \\
\text { of leaves* }\end{array}$} & \multicolumn{2}{|c|}{$\begin{array}{l}\text { Plant } \\
\text { height } \\
(\mathrm{cm})^{*}\end{array}$} & \multicolumn{2}{|c|}{$\begin{array}{c}\text { Flowering time } \\
\text { (month) }\end{array}$} \\
\hline & & & & & NT & $\mathrm{T}$ & NT & $\mathrm{T}$ & NT & $\mathrm{T}$ \\
\hline 1 & 25 & $10 / 25(0.4)$ & $4 / 6(0.67)$ & $3 / 5(0.6)$ & 18 & 17 & 125 & 120 & 6 & 5 \\
\hline 2 & 25 & $11 / 25(0.44)$ & $\begin{array}{c}5 / 8 \\
(0.625)\end{array}$ & $4 / 5(0.8)$ & 17 & 14 & 120 & 115 & 6 & 5 \\
\hline 3 & 25 & $15 / 25(0.6)$ & $3 / 6(0.5)$ & $4 / 5(0.8)$ & 17 & 17 & 130 & 120 & 6 & 5 \\
\hline
\end{tabular}

*5 months old; NT: non-transformant, T: transformant 
pass through the E.coli cell wall and membrane, with $\mathrm{Ca}^{2+}$ ions neutralizing the negative charges in DNA molecules so the DNA could more readily enter the cells following heat shock treatment (Casali, 2003). At the same time multiplication of pGAS101::GFP recombinant plasmids was occurred.

Checking whether bacteria carry pGAS101, pSK35S::GFP, and p35S::PaFT135S::GFP plasmids was performed by colony PCR to amplify DNA fragments using two pairs of primers, the DegPaFT F1 - R1 and sGFP Fw - Nos Rev. Amplified DNA fragments matching the sizes of GFP and PaFT1 genes, respectively were detected (Figure $3 \mathrm{D}$ and $\mathrm{E}$ ).

The p35S::PaFT1-35S::GFP recombinant plasmid was isolated from E. coli strain DH5a. The plasmid was then transformed into competent cells of A. tumefaciens strain EHA101. Procedures of plasmid transformation into competent cells of A. tumefaciens was adopted from a method described by Widyasari and Suhandono (2007). The p35S::PaFT1-35S::GFP recombinant plasmid was isolated from A. tumefaciens strain EHA101, and then it was checked by electrophoresis and visualized with UV Transilluminator (Figure 4).

The p35S::PaFT1-35S::GFP/A. tumefaciens EHA101 plasmid obtained as transformation products were checked using PCR with 2 pairs of primers, the degPaFT F2 - deg PaFT
R1 and sGFP Fw - Nos Rev. The PCR products showed the presence of PaFT1 and GFP genes (Figure 3).

Thus, the recombinant p35S::PaFT135S::GFP/A. tumefaciens strain EHA101 was ready to be used for genetic tobacco transformation to accelerate flowering. Examination of the tobacco leaves under UV light showed the bright green fluorescence of GFP in the leaves of 2.5 months old transformants. (Figure 5, Table 1).

To examine gene expression in transformant plants, we used RT-PCR using gene-specific primers. This method was also used by Semiarti et al. (2010) to detect GFP gene insertion in P. amabilis orchid protocorms, to evaluate transgenic plants carrying a copperinducible reporter gene expression system in Arabidopsis thaliana by Saijo and Nagasawa (2015), to evaluate the efficiency of T-DNA delivery in transformants of Phalaenopsis violacea by Zulkifle et al. (2010) and to analyze FT expression in plant by Xu et al. (2012). In this study, PaFT1 and GFP transcripts were detected in putative p35S::PaFT1-35S::GFP transgenic tobacco plants (Figure 6) indicating that the T-DNA of p35S::PaFT1-35S::GFP was integrated into the tobacco genome and functionally active. Transgenic tobacco plants with p35S::PaFT1-35S::GFP construct showed accelerated flowering with 14-17 leaves and $115-120 \mathrm{~cm}$ height at 5 months whereas wild
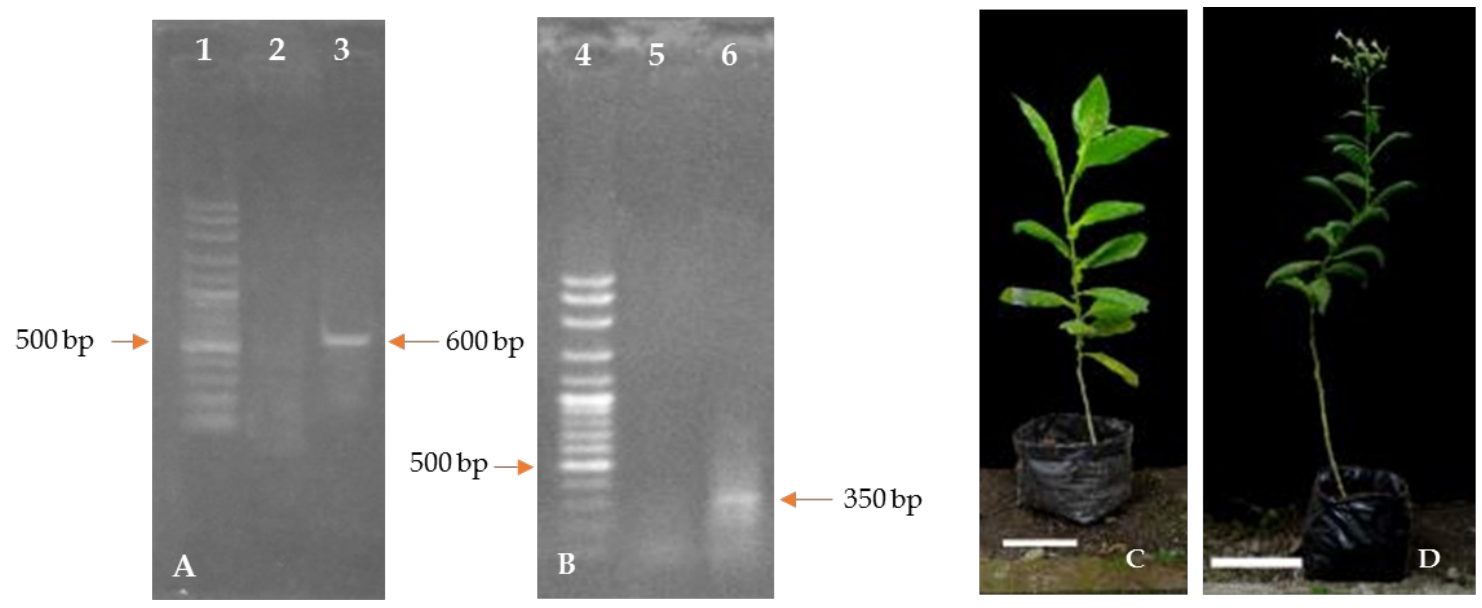

Figure 6. Early flowering of N. tabacum induced by p35S::PaFT1-35S::GFP. Detection of PaFT (A) and GFP (B) expression in the putative transgenic tobacco containing p35S::PaFT1-35S::GFP by RT-PCR. (Lane 1 and 4, 100 bp DNA Ladder; lane 2 and 5, non-transformant plants; lane 3 and 6, transformant plants). (C) 5 month-old wild type/non-transformed plant. (D) 5 month-old transgenic plant. Bars $25 \mathrm{~cm}$. 
type (non-transformant) plants flowered around one month later than transgenic tobacco plants with more leaves (Table 1, Figure 6C and 6D).

These results indicate that $\mathrm{PaFT1}$ can mildly reduce the vegetative growth period and accelerate flowering in tobacco. The use of GFP for efficient and early detection of transgenes was very helpful for early judgement of positive transformants.

\section{Conclusions}

The use of GFP for p35S::PaFT1-35S::GFP construct creates an efficient system for Agrobacterium-mediated plant transformation in plant. The recombinant plasmid, p35S::PaFT1-35S::GFP is a potential tool for genetic transformation in plants to accelerate flowering.

\section{Acknowledgements}

The authors thank the Directorate General of Higher Education (DGHE), Ministry of Education and Culture of RI for the Scholarship of National Graduate Study Program and for Doctor Research Grant to S.W, and for STRANAS research grant for 3 years (2012-2014) to E.S., PUPT UGM and PMDSU Research Grants (2016-2017) to ES and MDL. We wish also to thank Saka Wijaya for help to set the picture.

\section{References}

Brito, R.C.H., Carvalho, J.L., Zonari, A.A.C., Breyner, N.M., Carvalho, L., Gomes, D.A., and Goes, A.M. 2013. Genotype and expression of the enhanced green fluorescent protein in LEW-Tg (EGFP) F455.5/Rrrc rats. Braz. J. Vet. Res. Anim. Sci., 50(2), 87-97.

Casali, N. (2003) Escherichia coli host strains. In E. coli Plasmid Vectors Methods and Applications (N. Casali and A. Preston, eds.) p 27. Humana Press, Inc.

Chai, D., and Yu, H. 2007. Recent Advances in Transgenic Orchid Production. Orchid Sci. Biotechnol., 1(2), 34-39.

Ghorbel, R., Juarez, J., Navarro, L., and Pena, L. 1999. Green fluorescent protein as a screenable marker to increase the efficiency of generating transgenic woody fruit plants. Theor. Appl. Genet., 99, 350-358.

Hraska, M., Rakousky, S., and Curn, V. 2006. Green fluorescent protein as a vital marker for non-destructive detection of transformation events in transgenic plants. Plant Cell Tissue Organ Cult., 86, 303-318.

Jang, S., Choi, S-C, Li, H-Y., An, G., Schmelzer, E., 2015. Functional Characterization of Phalaenopsis aphrodite Flowering Genes PaFT1 and PaFD. PLoS ONE, 10(8), e0134987. doi:10.1371/journal pone.0134987

Julkiflie, A.L., Rathinam, X., Sinniah, U.R., and Subramaniam, S. 2010. Optimisation of Transient Green Fluorescent Protein (GFP) Gene Expression in Phalaenopsis Violacea Orchid Mediated by Agrobacterium Tumefaciens-mediated Transformation System. Aust. J. Basic \& Appl. Sci., 4(8), 3424-3432.

Ko, T., and Korban, S. 2004. Enhancing the frequency of somatic embyogenesis following Agrobacterium-mediated transformation of immature cotyledons of soybean (Glycine max (L.) Merrill). In Vitro Cell Dev. Biol-Plant., 40, 552558

Kojima, S., Banno, H., Yoshioka, Y., Oka, A., Machida, C., and Machida, Y. 1999. A binary vector plasmid for gene expression in plant cells that is stably maintained in Agrobacterium cells. DNA Res., 6, 407-410.

Madigan, M.T., Martinko, J.M., Stahl, D.A., and Clark, D.P. (2012) Brock Biology of Microorganisms. San Francisco: Pearson Education, Inc. p 160.

Miki, B., and McHugh, S. 2004. Selectable marker genes in transgenic plants: applications, alternatives and biosafety. J. Biotechnol., 107, 193-232.

Mohammed, A., and Abalaka, M.E. 2011. Agrobacterium transformation: A boost to agricultural Biotechnology. J. Med. Genet. Genomics, 3(8), 126 - 130.

Puchta, H. 2003. Marker-free transgenic plants. Plant Cell, Tissue and Organ 
Cult., 74, 123-134.

Saijo, T. and Nagasawa, A. 2015. A new detection tool for bioavailable copper utilizing transgenic plants carrying recombinant yeast ACE1 transcription factor and GFP reporter genes. Soil Sci. Plant Nutr., 61, 281-286

Sambrook, J., and Russell, D.W. (2001) Molecular Cloning. New York: Cold Spring Harbor Laboratory Press. p 8.18. Semiarti, E., Indrianto, A., Purwantoro, A., Martiwi, I.N.A., Feroniasanti, Y.M.L., Nadifah, F., Mercuriani, I.S., Dwiyani, R., Iwakawa, H., Yoshioka, Y., Machida, Y., and Machida, C. (2010) Highfrequency genetic transformation of Phalaenopsis amabilis orchid using tomato extract-enriched medium for the pre-culture of protocorms. J. Hortic. Sci. Biotechnol., 85(3), 205-210

Stewart, C.N. Jr. 2005. Monitoring the presence and expression of transgenes in living plants. Trends Plant Sci., 10(8), 390-396.

Widyasari, W. B, and Suhandono, S. 2007. Konstruksi vektor biner untuk ekspresi gen dipp22 (yang diisolasi dari tebu varietas M 442-51) pada tanaman. Berk. Penel. Hayati, 13, 15-26.

Xia, N., Luo,W., Zhang, J., Xie, X., Yang, H., Li, S., Chen, M., and Ng, M. 2002. Bioluminescence of Aequorea macrodactyla, a Common Jellyfish Species in the East China Sea. Mar. Biotechnol., 4, 155-162.

Xu, F., Rong, X., Huang, X., and Cheng, S. 2012. Recent Advances of Flowering Locus T Gene in Higher Plants. Int. J. Mol. Sci., 13, 3773-3781.

Yuwono, T. (2006) Bioteknologi Pertanian. Yogyakarta: Gadjah Mada University Press. pp 14, 217. 